\title{
Episodes of violence suffered by migrants transiting through Libya: a cross-sectional study in "Médecins du Monde's" reception and healthcare centre in Seine-Saint-Denis, France
}

\author{
L. Reques* (10, E. Aranda-Fernandez, C. Rolland, A. Grippon, N. Fallet, C. Reboul, N. Godard and N. Luhmann
}

\begin{abstract}
Introduction: The Central Mediterranean Route, passing through Libya, is one of the most dangerous for migrants. Episodes of violence have been documented but have not been accurately quantified. The objective of the study was to estimate the prevalence of episodes of violence suffered in Libya by migrants consulting the Médecins du Monde reception and healthcare centre in Seine-Saint-Denis (lle-de-France).

Methodology: A monocentric cross-sectional study was conducted from February to May 2019 including migrants over the age of 18 years who had passed through Libya and arrived in Europe from 2017. The presence of emotional distress was considered as exclusion criterion. The proportion, frequency and factors associated to physical, deprivation and sexual violence in Libya were estimated through a bespoke questionnaire, as well as healthcare access in Libya and psychosocial support needs.

Results: Ninety eight people were recruited and 72 were interviewed (17 refused to participate and 9 were excluded). $76.4 \%$ were men, with a mean age of 31.9 years, $76.4 \%$ had low educational level, $66.7 \%$ came from Ivory Coast and $59.7 \%$ had left their country for security reasons. The median length of stay in Libya was 180 days. The overall proportion of participants having suffered from violence was $96.4 \%$ among men and $88.2 \%$ among women. The prevalence of physical, deprivation and sexual violence for men and women were 94.2, 81.7 and 18\% and 80.0, 86.7 and 53.3\%, respectively. Access to healthcare in Libya was 2.8 and $63.9 \%$ of participants were oriented to psychosocial support after the interview.

Conclusions: The vast majority of migrants reported having been victims of violence during their transit through Libya. Women were at particular risk of sexual violence. Access to health care in Libya was almost non-existent. Psychosocial support for this population is urgent.
\end{abstract}

Keywords: Migration, Violence, Libya, Healthcare access

\footnotetext{
* Correspondence: requeslaura@hotmail.com

Médecins du Monde, 62 rue Marcadet, 75018 Paris, France
}

(c) The Author(s). 2020 Open Access This article is distributed under the terms of the Creative Commons Attribution 4.0 International License (http://creativecommons.org/licenses/by/4.0/), which permits unrestricted use, distribution, and reproduction in any medium, provided you give appropriate credit to the original author(s) and the source, provide a link to the Creative Commons license, and indicate if changes were made. The Creative Commons Public Domain Dedication waiver (http://creativecommons.org/publicdomain/zero/1.0/) applies to the data made available in this article, unless otherwise stated. 


\section{Background}

Several reports show that violence related to migration, including physical assault, torture and sexual violence, is a sad reality [1-3]. Among the migratory routes, the Central Mediterranean, which crosses Libya, is one of the most dangerous [2] .

Libya has been frequently indexed by the media for its dysfunctional migration policy and several international organisations have collected evidence and testimonies recounting the violence suffered by migrants [4-6]. Nevertheless, there are no scientific studies collecting quantitative evidence on this subject.

The objectives of this study were to quantify the violence episodes according to their typology; to determine its associated factors, as well as to assess healthcare access and need for psychosocial support among migrants having transited Libya and visiting the Médecins du Monde $(\mathrm{MdM})$ reception and healthcare centre in Seine-Saint-Denis (Ile-de-France).

\section{Methods}

The study was cross-sectional and monocentric. The target population was the beneficiaries of the MdM reception and healthcare centre in Seine-Saint-Denis. Individuals aged over 18 years old, with foreign nationality, having transited through Libya and having arrived in Europe from 2017 were included. Participants were excluded if they presented emotional distress, due to the risk of further psychological distress linked to the evocation of traumatic events. The presence of emotional distress was assessed by the Refugee Health Screener-15 (RHS-15) [7].

Patients were recruited during medical consultations. Once they had consented to participate they were interviewed in a confidential space by an specialised doctor, who had previously evaluated the exclusion criteria.

A sample size of 72 individuals was set according to a prevalence of violence of $95 \%$, a margin of error of $5 \%$ and a confidence interval (CI) of $95 \%$. Sampling was exhaustive until accomplishing the sample size.

The data collection tool was a bespoke online survey (KoboTool Box). Data were automatically added to a secure database. A two-weeks pre-test period was conducted in order to test the survey feasibility.

The study was conducted in French and assessed for two types of violence: direct and witnessed. In both cases, physical, sexual and deprivation violence episodes were tracked. Physical violence was divided in "episodes with firearms" (i.e. injury, aggression, shooting) and "episodes without firearms" (physical injury, beatings, threat). Sexual violence addressed "episodes of rape", deprivation violence included suffering from or witnessing "episodes of detention", "episodes of food deprivation", "episodes of confiscation", "episodes of racketeering", and "episodes of separation of family members". The frequency and the perpetrators of these episodes were also tracked. For the former it was set to "daily", "weekly", "less than once a week" or "very rare" and the latter was divided in "governmental forces", "armed groups", "civils" or "not identified". Healthcare access during the journey in Libya and need for psychosocial support after the interview were also assessed. Participants were oriented to psychosocial specialised teams after their agreement.

The descriptive analysis for continuous variables used mean \pm standard deviation, median, interquartile range and Student $\mathrm{T}$ tests. Percentages with a 95\% confidence interval and Chi2 tests were used for categorical variables. Stata v.15 software was used for statistical analysis.

This study was conducted in compliance with the ethical principles of the Helsinki Declaration. All participants received a written information sheet and their participation was voluntary after providing verbal informed consent. All information provided was anonymised and confidentiality was ensured. Participants could stop and/or refuse to continue the survey at any moment. Psychosocial support was available throughout the interview.

\section{Main findings}

Ninety eight people were recruited and 72 were interviewed from February to May 2019 (17 refused to participate and 9 were excluded due to emotional distress).

Table 1 describes the population and the episodes for the different violence types. Seventy two people were interviewed (55 men and 17 women). The mean age was 31.9 years old, $76.4 \%$ had primary studies, $66.6 \%$ came from Ivory Coast (followed by Mali 23.6\%) and 29.4\% of women were pregnant at some stage of the journey. The mean length of stay in Libya was 180 days and only $2.8 \%$ had access to healthcare during the stay. Sixty three point $9 \%$ of the participants looked for psychosocial support after the interview. Statistically significant differences by sex were found for the educational level ( $p=$ $0.03)$, the type of travel $(p=0.01)$ and healthcare access $(p=0.05)$.

According to the episodes of direct and witnessed violence, results show that $94.4 \%$ of the participants suffered some type of violence $(93.6 \%$ of men and $88.2 \%$ of women). Ninety one point $1 \%$ of participants suffered from physical violence $(80.0 \%$ of women and $94.3 \%$ of men). Eighty nine point $5 \%$ of participants experienced violence with deprivation $(81.7 \%$ of men and $86.7 \%$ of women) and $26.5 \%$ suffered sexual violence $(18.9 \%$ of men and $53.3 \%$ of women). In addition, $49.1 \%$ of men and $22.2 \%$ of women experienced forced labour and $17.6 \%$ of women had unsafe abortions during the journey. Differences by sex were statistically significant for physical, sexual violence and forced labour $(p<0.05)$.

One hundred percent of participants witnessed some kind of violence, with $93.1 \%$ witnessing episodes of 
Table 1 Sociodemographic characteristics and episodes of different types of violence in Libya by sex

\begin{tabular}{|c|c|c|c|c|c|c|c|}
\hline \multirow{2}{*}{ SOCIODEMOGRAPHIC CHARACTERISTICS } & \multicolumn{2}{|c|}{ Total $(N=72)$} & \multicolumn{2}{|c|}{ Women $(N=17)$} & \multicolumn{2}{|c|}{ Men $(N=55)$} & \multirow[t]{2}{*}{$p$ value } \\
\hline & & & & & & & \\
\hline Age in years (mean, SD) & 31,9 & $(7,4)$ & 30,2 & $(7,8)$ & 32,5 & $(7,3)$ & 0,27 \\
\hline \multicolumn{8}{|l|}{ Educational level $(\%, n / N)$} \\
\hline Primary & 76,4 & $(55 / 72)$ & 100,0 & $(17 / 17)$ & 69,1 & $(38 / 55)$ & \multirow[t]{3}{*}{$0,03^{*}$} \\
\hline Secondary & 18,1 & $(13 / 72)$ & 0,0 & $(0 / 17)$ & 23,6 & $(13 / 55)$ & \\
\hline Tertiary & 5,5 & $(4 / 72)$ & 0,0 & $(0 / 17)$ & 7,3 & $(4 / 55)$ & \\
\hline \multicolumn{8}{|l|}{ Country of Origin $(\%, n / N)$} \\
\hline Ivory Coast & 66,6 & $(48 / 72)$ & 82,4 & $(14 / 17)$ & 61,8 & $(34 / 55)$ & \multirow[t]{4}{*}{0,51} \\
\hline Mali & 23,6 & $(17 / 72)$ & 17,6 & $(3 / 17)$ & 25,5 & $(14 / 55)$ & \\
\hline Eritrea & 1,4 & $(1 / 72)$ & 0,0 & $(0 / 17)$ & 1,8 & $(1 / 55)$ & \\
\hline Republic of Cameroon & 5,6 & $(4 / 72)$ & 0,0 & $(0 / 17)$ & 7,3 & $(4 / 55)$ & \\
\hline \multicolumn{8}{|l|}{ Reasons for leaving country of origin $(\%, n / N)$} \\
\hline Security & 59,7 & $(43 / 72)$ & 82,3 & $(14 / 17)$ & 52,7 & $(29 / 55)$ & \multirow[t]{4}{*}{0,12} \\
\hline Political & 15,3 & $(11 / 72)$ & 5,9 & $(1 / 17)$ & 18,2 & $(10 / 55)$ & \\
\hline Economic & 22,2 & $(6 / 72)$ & 11,8 & $(4 / 17)$ & 25,5 & $(14 / 55)$ & \\
\hline Studies & 2,8 & $(2 / 72)$ & 0,0 & $(0 / 17)$ & 3,6 & $(2 / 55)$ & \\
\hline \multicolumn{8}{|l|}{ Type of travel $(\%, n / N)$} \\
\hline Alone & 69,4 & $(50 / 72)$ & 41,2 & $(7 / 17)$ & 78,2 & $(43 / 55)$ & \multirow[t]{3}{*}{$0,01^{*}$} \\
\hline With family & 19,4 & $(14 / 72)$ & 35,3 & $(6 / 17)$ & 14,5 & $(4 / 55)$ & \\
\hline Other & 11,1 & $(8 / 72)$ & 23,5 & $(4 / 17)$ & 7,3 & $(8 / 55)$ & \\
\hline Pregnancy during travel $(\%, \mathrm{n} / \mathrm{N})$ & - & - & 29,4 & $(5 / 17)$ & - & - & - \\
\hline Boarding by threat $(\%, \mathrm{n} / \mathrm{N})$ & 58,1 & $(42 / 72)$ & 47,1 & $(8 / 17)$ & 61,8 & $(34 / 55)$ & 0,68 \\
\hline Length of stay in Libya in days (median, IQR) & 180 & $(120-365)$ & 120,0 & $(60-180)$ & 200 & $(120-365)$ & $0,02^{*}$ \\
\hline Healthcare access in Libya $(\%, \mathrm{n} / \mathrm{N})$ & 2,8 & $(2 / 72)$ & 0 & $(0 / 17)$ & 3,6 & $(2 / 55)$ & $0,05^{*}$ \\
\hline Need of psychological support after the survey $(\%, n / N)$ & 63,9 & $(46 / 72)$ & 70,8 & $(12 / 17)$ & 61,8 & $(34 / 55)$ & 0,35 \\
\hline \multicolumn{8}{|l|}{ EPISODES OF DIRECT VIOLENCE (\%, CI 95\%) } \\
\hline Global Violence ${ }^{1}$ & 94,4 & $(89,0-99,9)$ & 88,2 & $(71,3-100)$ & 96,3 & $(91,3-100)$ & 0,21 \\
\hline Physical violence & 91,1 & $(84,3-98,1)$ & 80,0 & $(57,1-100)$ & 94,3 & $(87,9-100)$ & $0,05^{*}$ \\
\hline With firearms & 76,1 & $(65,6-86,6)$ & 53,5 & $(24,7-81,9)$ & 82,7 & $(72,1-93,3)$ & $0,02^{*}$ \\
\hline Without firearms & 89,5 & $(82,1-97,1)$ & 73,3 & $(48,0-98,7)$ & 94,3 & $(87,9-100)$ & $0,02^{*}$ \\
\hline Violence with deprivation & 89,5 & $(82,1-97,1)$ & 86,7 & $(67,7-100)$ & 91,7 & $(85,6-100)$ & 0,10 \\
\hline Detention without food & 88,2 & $(79,3-98,1)$ & 86,7 & $(67,7-100)$ & 88,7 & $(78,3-99,0)$ & 0,85 \\
\hline Detention with racket & 58,8 & $(46,1-71,5)$ & 46,7 & $(18,1-75,2)$ & 62,3 & $(47,7-76,8)$ & 0,31 \\
\hline Detention with ransom & 58,8 & $(46,1-71,5)$ & 60,1 & $(31,9-88,0)$ & 58,5 & $(43,8-73,2)$ & 0,92 \\
\hline Family separation & 37,6 & $(24,2-49,2)$ & 46,7 & $(18,1-75,2)$ & 34,0 & $(19,7-48,2)$ & 0,40 \\
\hline Sexual violence & 26,5 & $(15,7-37,2)$ & 53,3 & $(24,7-81,9)$ & 18,9 & $(7,9-24,8)$ & $0,01^{*}$ \\
\hline \multicolumn{8}{|l|}{ Other types of violence } \\
\hline Forced labour & 33,3 & $(19,9-47,5)$ & 22,2 & $(9,8-35,6)$ & 49,1 & $(17,5-82,1)$ & $0,03^{*}$ \\
\hline Unsafe abortion & - & - & 17,6 & $(5,3-29,9)$ & - & - & - \\
\hline \multicolumn{8}{|l|}{ EPISODES OF WITNESSED VIOLENCE (\%, CI 95\%) } \\
\hline Global Violence $^{1}$ & 100,0 & $(100-100)$ & 00,0 & $(100-100)$ & 100,0 & $(100-100)$ & - \\
\hline Physical violence & 93,1 & $(85,9-100)$ & 88,2 & $(71,1-100)$ & 94,3 & $(87,9-100)$ & 0,46 \\
\hline With firearms & 87,5 & $(78,7-93,2)$ & 82,4 & $(62,1-100)$ & 89,1 & $(79,1-99,0)$ & 0,52 \\
\hline Without firearms & 93,1 & $(85,9-100)$ & 88,2 & $(71,1-100)$ & 92,7 & $(83,9-100)$ & 0,87 \\
\hline
\end{tabular}


Table 1 Sociodemographic characteristics and episodes of different types of violence in Libya by sex (Continued)

\begin{tabular}{|c|c|c|c|c|c|c|c|}
\hline \multirow[b]{2}{*}{ Violence with deprivation } & \multicolumn{2}{|c|}{ Total $(N=72)$} & \multicolumn{2}{|c|}{ Women $(N=17)$} & \multicolumn{2}{|c|}{ Men $(N=55)$} & \multirow{2}{*}{$\frac{p \text { value }}{0,21}$} \\
\hline & 94,4 & $(89,0-99,9)$ & 88,2 & $(71,3-100)$ & 96,3 & $(91,3-100)$ & \\
\hline Detention without food & 87,5 & $(78,3-96,5)$ & 88,2 & $(71,2-100)$ & 87,3 & $(76,8-97,7)$ & 0,93 \\
\hline Detention with racket & 76,4 & $(65,6-87,1)$ & 76,4 & $(54,0-99,0)$ & 76,4 & $(63,7-89,1)$ & 0,99 \\
\hline Detention with ransom & 79,2 & $(68,8-89,6)$ & 70,6 & $(46,4-94,7)$ & 81,8 & $(70,1-93,6)$ & 0,37 \\
\hline Family separation & 61,1 & $(48,9-73,3)$ & 52,9 & $(26,5-79,4)$ & 63,6 & $(49,5-77,6)$ & 0,46 \\
\hline Sexual violence & 79,2 & $(68,8-89,6)$ & 82,4 & $(62,1-100)$ & 78,2 & $(65,8-90,6)$ & 0,74 \\
\hline \multicolumn{8}{|l|}{ Other types of violence } \\
\hline Forced labour & 88,2 & $(79,3-98,1)$ & 86,7 & $(67,7-100)$ & 88,7 & $(78,3-99,0)$ & 0,85 \\
\hline
\end{tabular}

1 The term Global violence refers to physical and/or deprivation and/or sexual violence ${ }^{*} p$ values correspond to two sample T-tests for continuous variables and to Chi-2 tests for categorical values. Values with * are statistically significant $(p<0.05)$. SD Standard deviation, IQR Interquartile range

physical violence, $94.4 \%$ episodes of deprivation violence, $79.2 \%$ episodes of sexual violence and $88.2 \%$ other type of episodes of violence. No statistically significant differences by sex were found.

Table 2 describes episodes of physical, deprivation and sexual violence by sociodemographic characteristics and other secondary variables. Apart from differences by sex, no statistically significant differences were found by other variables.

In addition, related to the frequency of physical violence episodes, $38 \%$ of participants reported daily violence, $48 \%$ weekly violence, $15 \%$ less than weekly and 5\% rarely. These percentages were 37, 54, 9 and $0 \%$ for deprivation violence and $41,25,34$ and $0 \%$ for sexual violence, respectively. In $54 \%$ of the cases perpetrators were not identified, $29 \%$ were identified as civils, $10 \%$ as armed groups and $7 \%$ as governmental forces.

\section{Discussion}

Human rights' violations in Libya have been documented for years by international organizations, think tanks and journalists [4, 8-10]. Nevertheless, this evidence come

Table 2 Episodes of direct physical, deprivation and sexual violence by secondary variables

\begin{tabular}{|c|c|c|c|c|c|c|c|c|c|c|c|c|}
\hline \multirow[b]{2}{*}{$(N=72)$} & \multicolumn{3}{|c|}{ Global violence $^{1}$} & \multicolumn{3}{|c|}{ Physical violence } & \multicolumn{3}{|c|}{ Deprivation violence } & \multicolumn{3}{|c|}{ Sexual violence } \\
\hline & No & Yes & $p$ & No & Yes & $p$ & No & Yes & $p$ & No & Yes & $p$ \\
\hline \multicolumn{13}{|l|}{ Sex (\%) } \\
\hline Male & 3,4 & 96,4 & 0,20 & 5,7 & 94 & 0,08 & 15,1 & 84,9 & 0,87 & 81,1 & 18,9 & $0,01^{*}$ \\
\hline Female & 11,6 & 88,2 & & 20 & 80 & & 13,3 & 86,7 & & 46,7 & 53,3 & \\
\hline \multirow[t]{2}{*}{ Age in years (mean, SD) } & 30 & 32 & 0,53 & 31 & 31,8 & 0,75 & 32 & 30,5 & 0,61 & 30,7 & 34,4 & 0,71 \\
\hline & $(5,0)$ & $(7,6)$ & & $(7,0)$ & $(8,6)$ & & $(6,7)$ & $(7,9)$ & & $(6,1)$ & $(8,6)$ & \\
\hline \multicolumn{13}{|l|}{ Level of Education (\%) } \\
\hline Primary & 5,5 & 94,6 & 0,16 & 7,7 & 92,3 & 0,31 & 11,5 & 86,5 & 0,82 & 71,2 & 28,9 & 0,52 \\
\hline Secondary & 0 & 100 & & 7,7 & 92,3 & & 15,4 & 84,6 & & 76,9 & 23,1 & \\
\hline Tertiary & 25 & 75,0 & & 33,3 & 66,7 & & 33,3 & 66,7 & & 100,0 & 0 & \\
\hline \multicolumn{13}{|l|}{ Country of Origin (\%) } \\
\hline Ivory Coast & 4,1 & 95,8 & 0,09 & 8,7 & 90,3 & 0,8 & 13,0 & 84,8 & 0,98 & 80,4 & 19,6 & 0,17 \\
\hline Mali & 5,9 & 94,1 & & 6,5 & 93,8 & & 18,8 & 81,3 & & 50,0 & 50 & \\
\hline Eritrea & 0 & 100 & & 25 & 75 & & 0,0 & 100 & & 100,0 & 0 & \\
\hline Republic of Cameroon & 33,3 & 66,7 & & 0 & 100 & & 0,0 & 100 & & 75,0 & 25 & \\
\hline \multicolumn{13}{|l|}{ Type of travel (\%) } \\
\hline Alone & 6 & 94 & 0,45 & 6,4 & 93,6 & 0,57 & 14,9 & 83 & 0,79 & 74,5 & 25,5 & 0,55 \\
\hline With family & 0 & 100 & & 14,3 & 85,7 & & 14,3 & 85,7 & & 64,5 & 35,7 & \\
\hline Other & 12,5 & 87,5 & & 14,3 & 85,7 & & 0,0 & 100 & & 85,7 & 14,3 & \\
\hline \multirow[t]{2}{*}{ Length of stay in Libya (mean, SD) } & 118,3 & 259,5 & 0,79 & 122,5 & 270,3 & 0,81 & 104,3 & 277,4 & 0,83 & 109,3 & 268,5 & 0,86 \\
\hline & $(70,1)$ & $(116,2)$ & & $(72,1)$ & $(126,6)$ & & $(76,1)$ & $(135,9,2)$ & & $(65,1)$ & $(126,2)$ & \\
\hline
\end{tabular}

${ }^{*} p$ values correspond to two sample T-tests for continuous variables and to Chi-2 tests for categorical values. Values with ${ }^{*}$ are statistically significant $(p<0.05)$. $S D$ Standard deviation 
mainly from individual testimonies, reports or press releases. The added value of our study resides in its methodology which enables the quantification of the prevalence of these episodes in migrants hosted in a European country when arriving to a reception centre.

Our results show that the vast majority of people suffered from long imprisonment and confinement, where violence was systematic and of a huge magnitude. In most cases, the episodes of physical violence were suffered every day or almost every day and deprivation episodes lasted for the whole journey. In addition, perpetrators were very difficult to identify (more than a half of the participants simply called them "the Arabs").

Several NGOs and international agencies have reported that physical violence occurs mainly in places of confinement and is closely linked to the exploitation of migrants, forced labour and extortion $[4,11,12]$. Firearms are very common and often used for threat, but episodes of mass murders and shootings have also been documented. Several reports mention extortion as a common practice. However, NGOs note that migrants are often abducted by smugglers when they arrive in the country. They can be released if they pay, themselves or their families but they can also be sold to another smuggling group $[4,11]$.

In our study, women were particularly vulnerable to sexual violence. This has also been documented by other reports pointing that sexual violence is a common practice during the detentions or before being released [13-16]. One third of the victims of sexual violence of the study stated that episodes were very common (daily or almost daily and by multiple perpetrators). Nevertheless, this type of violence might have been underestimated, especially for men, as the nature of the violence, which affects their privacy, sexuality and gender identity, makes it difficult for them to speak up.

Our study shows that none of the participants had ever been treated by a doctor or had received medication during their journey. It has been documented that the health system in Libya has collapsed and it is facing serious problems due to infrastructure damage, lack of medicines, medical equipment and staff $[10,17]$.

Most people asked for psychological support after the questionnaire, reflecting a real urgency. The literature has well documented how mental health disorders occur as a consequence of migration, mainly linked to forced, unplanned, poorly planned or illegal migration, low educational level, isolation, lack of support and perceived discrimination [18-20].

\section{Limitations}

The profile of participants is restricted to the recruitment location, which limits the external validity of the study. In addition, it is reasonable to assume that participants with emotional distress may have experienced higher levels of exposure to violent events and therefore their exclusion from the study may have resulted in an under-estimate of overall levels of violence exposure. Sexual violence might also have been underestimated, especially among men, as it was normally evoked as witnessed. Finally, the low proportion of women could limit the statistical power for this group.

\section{Conclusions}

Our study of migrants presenting at the MdM reception and healthcare centre in Seine-Saint-Denis showed that the vast majority were victims of violence during their transit through Libya. Women were at particular risk of sexual violence. Access to health care in Libya was almost non-existent. Psychosocial support for this population is urgent.

\section{Abbreviations \\ Cl: Confidence Intervalle; INSERM: Institut national de la santé et de la recherche médicale; IQR: Inter Quartile Range; IRB: Institutional Review Board; MdM: Médecins du Monde; NGO: Non-Governmental Organization; RHS- 15: Refugee Health Screener 15; SD: Standard Deviation}

\section{Acknowledgements}

We are grateful to all the participants of this study for their valuable testimonies. We are also grateful to all volunteers and employees who collaborated in the different stages of the study, and all the collaborators in MdM headquarters (France operations, Communication and Health and Advocacy Directions).

\section{Authors' contributions}

$\mathrm{NL}, \mathrm{CR}, \mathrm{ChR}, \mathrm{NG}, \mathrm{AG}$ and NF participated on the study conception and design. $L R$, EAF, CR, AG and NF implemented and coordinated the data collection. LR and EAF conducted the data analysis. LR and EAF wrote the first article draft. All authors commented on the draft and provided substantial inputs. All authors read and approved the final version of the article.

\section{Funding}

Médecins du Monde.

Availability of data and materials

The datasets used and/or analysed during the current study are available from the corresponding author on reasonable request.

\section{Ethics approval and consent to participate}

This research project was approved by the INSERM Institutional Review Board (IRB). The study was conducted in compliance with the ethical principles of the Helsinki Declaration. All participants were informed of the study's objectives and design, and their participation was voluntary after providing verbal informed consent.

Consent for publication

Not applicable.

Competing interests

The authors declare that they have no competing interests.

Received: 2 January 2020 Accepted: 29 January 2020

Published online: 28 February 2020

\section{References}

1. Altai Consulting. Mixed migration trends in Libya: Changing dynamics and protection challenges, Altai Consulting in partnership with IMPACT Initiatives, for the UNHCR in Libya, 2017 [Internet]. Disponible sur: http:// 
www.altaiconsulting.com/wp-content/uploads/2017/08/2017_MixedMigration-Trends-in-Libya-Final-Report-Web.pdf.

2. UNHCR. Mediterranean Situation [Internet]. Disponible sur: https://data2. unhcr.org/en/situations/mediterranean/location/5205.

3. IOM. Four decades of cross Mediterranean. four_decades_of_cross_ mediterranean [Internet]. 2019. Disponible sur: https://publications.iom.int/ system/files/pdf/four_decades_of_cross_mediterranean.pdf.

4. Amnesty International. EU risks fuelling horrific abuse of refugees and migrants in Libya [Internet]. 2016. Disponible sur: https://www.amnesty.org/ en/latest/news/2016/06/eu-risks-fuelling-horrific-abuse-of-refugees-andmigrants-in-libya/.

5. Dollet S. Violence perpetrated in Libya against exiled persons \& consequences on health observed after arrival in Europe a focus on the impact of EU as well as Italian \& French policies. Médecins du Monde; 2018.

6. DMT. Libya - Migrant Report Information Package 18 (March 2018) [Internet]. 2018. Disponible sur: https:/www.globaldtm.info/dtm-libyamigrant-report-information-package-18-march-2018/.

7. The Refugee Health Screener-15 (RHS-15): development and validation of an instrument for anxiety, depression, and PTSD in refugees. - PubMed NCBI [Internet]. [cité 7 janv 2020]. Disponible sur: https://www.ncbi.nlm.nih gov/pubmed/23347455.

8. Rights Watch. EU/NATO: Europe's plan endangers foreigners in Libya [internet]. Disponible sur: EU/NATO: Europe's Plan Endangers Foreigners in Libya.

9. Migreurop. Libya. The hounding of migrants must stop [Internet]. Disponible sur: http://www.migreurop.org//MG/pdf/109697240-ReportMigrants-Libya.pdf

10. Oun AM, Hadida EM, Stewart C. Assessment of the knowledge of blast injuries management among physicians working in Tripoli hospitals (Libya). Prehosp Disast Med Juin. 2017;32(3):311-6.

11. MSF. Arbitrary detention of refugees, asylum-seekers and migrants must stop [Internet]. 2017. Disponible sur: https://www.msf.org/libya-arbitrarydetention-refugees-asylum-seekers-and-migrants-must-stop.

12. MEDU. Rapporto sulle condizioni di grave violazione dei diritti umani dei migranti in Libia (2014-2017) [Internet]. 2018. Disponible sur: http://www. mediciperidirittiumani.org/wp-content/uploads/2017/12/Rapporto-perTribunale-Permanente-dei-Popoli.pdf.

13. DRC. Going West. Migration trends from Libya to Europe [Internet]. Disponible sur: https://drc.ngo/media/2846076/going_west_migration_ trends_libya_europe_final.pdf.

14. Amnesty International. Refugees and migrants fleeing sexual abuse and explotaition in Libya [Internet]. 2016. Disponible sur: https://www. amnestyusa.org/press-releases/refugees-and-migrants-fleeing-sexualviolence-abuse-and-exploitation-in-libya/.

15. Freedman J. Sexual and gender-based violence against refugee women: a hidden aspect of the refugee « crisis ». Reprod Health Matters Mai. 2016 24(47):18-26.

16. Vu A, Adam A, Wirtz A, Pham K, Rubenstein L, Glass N, et al. The Prevalence of Sexual Violence among Female Refugees in Complex Humanitarian Emergencies: a Systematic Review and Meta-analysis. PLoS Curr. 2014;6.

17. Zarocostas J. Libya: war and migration strain a broken health system. Lancet Lond Engl. 2018;391(10123):824-825.

18. Crepet A, Rita F, Reid A, Van den Boogaard W, Deiana P, Quaranta G, et al. Mental health and trauma in asylum seekers landing in Sicily in 2015: a descriptive study of neglected invisible wounds. Confl Health. 2017;11:1.

19. Abbott A. The mental-health crisis among migrants. Nature. 2016;538(7624): $158-160$.

20. Bianucci R, Charlier P, Perciaccante A, Lippi D, Appenzeller O. The « Ulysses syndrome »: an eponym identifies a psychosomatic disorder in modern migrants. Eur J Intern Med Juin. 2017:41:30-2.

\section{Publisher's Note}

Springer Nature remains neutral with regard to jurisdictional claims in published maps and institutional affiliations.

\section{Ready to submit your research? Choose BMC and benefit from:}

- fast, convenient online submission

- thorough peer review by experienced researchers in your field

- rapid publication on acceptance

- support for research data, including large and complex data types

- gold Open Access which fosters wider collaboration and increased citations

- maximum visibility for your research: over $100 \mathrm{M}$ website views per year

At BMC, research is always in progress.

Learn more biomedcentral.com/submissions 